\title{
An appraisal of pattern and presentation of gynaecological malignancies in Bowen University Teaching Hospital, Southwest Nigeria
}

\author{
*Ogunlaja O.A ${ }^{1}$, Akinola S.E ${ }^{1}$,Bakare Y.T ${ }^{1}$, Adeniran A.S ${ }^{2}$, Ogunlaja I.P ${ }^{3}$, Olasinde $A^{4}$, \\ Adetoye $\mathbf{F}^{1}$, Bowale $\mathrm{D}^{1}$, Kasali $\mathrm{O}^{1}$, Oladeji $\mathbf{I}^{1}$, Oyedele T.J ${ }^{1}$, Salawu B.T ${ }^{1}$
}

\begin{abstract}
Abstarct
Background: Gynaecological malignancies are cancers that occur in or on a woman's reproductive organs and genitals which includes the vulva, vagina, cervix, uterus, fallopian tubes, and ovaries. The prevalence of gynaecological malignancies varies from one country to another. The factors responsible for the observed variance includes lifestyle, dietary pattern, level of education and the sophistication of health care system. This study aims to identify the pattern and clinical presentations of gynaecological malignancies at Bowen University Teaching Hospital, Ogbomoso over a five-year period.
\end{abstract}

Methods: This was a retrospective study involving one hundred and twenty-three (123) patients with a histological diagnosis of gynecological malignancy.

Results: Patients with gynaecological malignancies accounted for $3.6 \%$ of the patients seen in the period under review. Majority of these patients were multiparous and between the age range of 50 and 69 years. The commonest form of gynaecological malignancy seen was cervical cancer.

Conclusion: Health care programs and policies that strengthen public awareness campaigns, health education and health promotion like human papilloma virus vaccination and follow up surveillance will help to reduce the morbidity and mortality associated with gynaecological malignancies.

Keywords: appraisal, pattern, presentation, gynaecological malignancies

\author{
*Corresponding Author \\ Ogunlaja O.A. \\ ORCID-NO: http://orcid.org/0000-0001 \\ Email address: lajamuyiwa@yahoo.com
}

\footnotetext{
${ }^{1}$ Department of Obstetrics \& Gynaecology, Bowen University Teaching Hospital, Ogbomoso, Nigeria

${ }^{2}$ Department of Obstetrics \& Gynaecology, University of Ilorin Teaching Hospital, Ilorin, Nigeria

${ }^{3}$ Department of Obstetrics \&Gynaecology, General Hospital, Ilorin, Nigeria

${ }^{4}$ Department of Obstetrics \& Gynaecology, Civil Service Hospital, Ilorin, Nigeria
} 


\title{
Une évaluation du modèle et de la présentation des malignances gynécologiques à l'hôpital d'enseignement de l'Université Bowen, au sud- ouest du Nigéria
}

\author{
*Ogunlaja O.A ${ }^{1}$, Akinola S.E ${ }^{1}$,Bakare Y.T ${ }^{1}$, Adeniran A.S ${ }^{2}$, Ogunlaja I.P ${ }^{3}$, Olasinde A $^{4}$, \\ Adetoye $\mathbf{F}^{1}$, Bowale $D^{1}$, Kasali $\mathbf{O}^{1}$, Oladeji $\mathbf{I}^{1}$, Oyedele T.J ${ }^{1}$, Salawu B.T ${ }^{1}$
}

\section{Résumé}

Objectif de l'étude: Les tumeurs malignes gynécologiques sont des cancers qui surviennent dans ou sur les organes reproducteurs et les organes génitaux d'une femme, notamment la vulve, le vagin, le col de l'utérus, l'utérus, les trompes de fallope et les ovaires. La prévalence des tumeurs malignes gynécologiques varie d'un pays à l'autre. Les facteurs responsables de la variance observée comprennent le mode de vie, les habitudes alimentaires, le niveau d'éducation et la sophistication du système de soins de santé. Cette étude vise à identifier le modèle et les présentations cliniques des tumeurs malignes gynécologiques au Bowen University Teaching Hospital, Ogbomoso sur une période de cinq (5) ans.

Méthode de l'étude: Il s'agissait d'une étude rétrospective portant sur cent vingt-trois (123) patientes avec un diagnostic histologique de malignité gynécologique.

Résultat de l'étude: Les patientes atteintes de malignités gynécologiques représentaient 3,6\% des patientes vues au cours de la période sous revue. La majorité de ces patients étaient multipares et âgés de 50 à 69 ans. La forme la plus courante de malignité gynécologique observée était le cancer du col de l'utérus.

Conclusion: Les programmes et politiques de soins de santé qui renforcent les campagnes de sensibilisation du public, l'éducation à la santé et la promotion de la santé comme la vaccination contre le virus du papillome humain et la surveillance de suivi aideront à réduire la morbidité et la mortalité associées aux malignités gynécologiques.

Mots-clés - Évaluation, modèle, présentation, malignances gynécologiques

\author{
*Corresponding Author \\ Ogunlaja O.A. \\ ORCID-NO: http://orcid.org/0000-0001 \\ Email address: lajamuyiwa@yahoo.com
}

\footnotetext{
${ }^{1}$ Department of Obstetrics \& Gynaecology, Bowen University Teaching Hospital, Ogbomoso, Nigeria

${ }^{2}$ Department of Obstetrics \& Gynaecology, University of Ilorin Teaching Hospital, Ilorin, Nigeria

${ }^{3}$ Department of Obstetrics \& Gynaecology, General Hospital, Ilorin, Nigeria

${ }^{4}$ Department of Obstetrics \& Gynaecology, Civil Service Hospital, Ilorin, Nigeria
} 


\section{INTRODUCTION}

Gynaecological malignancies is a term used for all the types of cancer that can occur in or on a woman's reproductive organs and genitals, these includes malignancies affecting the vulva, vagina, cervix, uterus, fallopian tubes and ovaries. These categories of cancers can be said to be relatively common in women, with the incidence and deaths due to gynaecological cancers on the rise globally, making it a health problem of global significance. These cancers account for about $10 \%$ of new cancer cases in women and $12 \%$ of cancer deaths. (1).

Globally, the prevalence of gynaecological malignancies varies from one region to another and one country to another. Some studies have shown that in developed countries, endometrial cancer is the more prevalent gynaecological malignancy, whereas in developing countries, cervical cancer is commoner. This variation can be attributed to factors such as lack or low levels of awareness, late presentation of patients with gynaecological malignancies and lack of routine screening programs, especially in developing countries; other factors includes differences in life style, dietary pattern, level of education and the sophistication of health care system. $(2,3,4)$

While obsolete screening system remains a major problem leading to the persistence of cervical cancers, Ovarian cancer has no established standard early diagnostic technique and most patients have non specific symptoms, hence most with ovarian cancer present in advanced stages of the disease. $(1,3,5)$ Mortality due to endometrial cancer is less compared to those of cervical and ovarian cancer because the stage at presentation is early which is amenable to treatment and has a better prognosis. It is important to state that women of high parity have relatively low risk of developing endometrial cancer. $(1,6)$ For the other forms of gynaecological malignancies, choriocarcinoma represents $0.6 \%$ of all gynaecological cancers with incidence rates highest in Southeast Asia. It is commonly seen in pre or perimenopausal women whereas vulval and vaginal cancers are rare with peak incidence in the sixth decade of life (3).

The aim of this study is to determine the pattern and clinical presentations of gynaecological malignancies of the female genital tract presenting to Bowen University Teaching Hospital, Ogbomoso over a five-year period (2015-2019). This study seeks to establish a database with regards to the pattern, relative frequencies and clinical presentations of gynecological cancers seen at the Bowen University Teaching Hospital. The information obtained from this study will be helpful in identifying the burden of gynaecological cancers in our environment with the aim of proposing primary, secondary and tertiary measures that will help in reducing the burden and impact of the disease on women and the society at large. These includes health education and promotion, screening programs, appropriate resource allocation, health planning and policy decisions.

\section{MATERIALS AND METHODS}

The study was conducted in Bowen University Teaching Hospital (BUTH), Ogbomosho, Oyo State, located in the southwestern part of Nigeria. Its coordinates is $8.1227^{\circ} \mathrm{N}, 4.2436^{\circ} \mathrm{E}$. It is $95 \mathrm{~km}$ north-west of the Oyo state capital (Ibadan). Ogbomosho has five local government areas (LGAs) with each having ten wards. The LGAs are in the regions of Ogbomosho North, Ogbomosho South, Surulere, Oriire, and Ogo-Oluwa. The hospital serves as a referral center for primary and secondary health care centers in Oyo State. Most of the people are of the Yoruba ethnic group. This retrospective study was conducted by reviewing medical records of patients who were diagnosed of gynecological malignancy over a period of 5 years (January 1,2015-December 31,2019). Data was retrieved, studied, and collated.

Inclusion criteria -All patients record files with proven diagnosis of gynecological malignancy and backed with histological evidence.

Exclusion criteria -Case files of patients without gynecological malignancy and those with incomplete entry or missing from the health records office

Information obtained from the patients' folders included - Patient's age, Parity, Occupation, Presenting Complaints, Nature of gynecological malignancy and Histological nature of the malignancy.

Ethical approval: Ethical approval was obtained from the Ethical committee of the Bowen University Teaching Hospital, Ogbomosho to conduct the research, and permission granted to access patient case files, Confidentiality of patients was ensured during the conduct of the study.

Data Analysis

Data was obtained and analyzed using statistical 
package for social science version 22. Frequency tables and chats were made, results were tested for significance using the t-test for continuous variables, and chi-square test for categorical variables. The level of significance was put at $\mathrm{P}$ value of 0.05 .

\section{RESULT}

During the five (5) year period under review, a total of One hundred and twenty-three (123) patients were diagnosed with one form of gynaecological malignancy or the other. These accounted for $3.6 \%$ of the Three thousand four hundred and eighteen (3418) new patients seen in the gynaecological outpatient clinic in the period under review.

The largest number of the study population was in the age group 50-59 and 60-69 with 35 patients $(28.5 \%)$ respectively, this was followed by the 40-49-year category with 22 patients $(17.9 \%)$.Table 1 . There was a statistically significant relationship between age of the women and diagnosis of gynaecological malignancies. $(p=0.001)$

The prevalence of these cancers are as shown in Figure 1. Cervical cancer was the commonest gynaecological cancer seen in Bowen University Teaching Hospital, Ogbomoso in the period under review. Another notable finding was that these cancers were commoner amongst multiparous women than nulliparous women hence there was a statistically significant relationship between parity and the diagnosis of gynaecological malignancies. $(\mathrm{p}<0.05)$.

Table 2 , shows that bleeding per vaginam was the commonest presenting complaint for cervical $(61 \%)$ and endometrial cancers $(13 \%)$, while presence of abdominal swelling was the commonest presenting complaint for Ovarian cancers (16\%). Weight loss was observed more in patients with cervical (35\%) and ovarian cancers $(12 \%)$. The presence of ascites was statistically significant amongst patients with Ovarian cancers when compared with other forms of gynaecological malignancies. $(p=0.001)$

When histological variants were considered it was observed that squamous cell carcinoma was the most common histological variants amongst the cervical cancers while serous cystadenocarcinoma was the more common form of ovarian cancer identified

\section{DISCUSSION}

In this study, gynaecological cancers accounted for $3.6 \%$ of gynaecological disease burden in our centre, this is similar to the $3.0 \%$ reported in Abuja and lower than $8.4 \%$ reported in Abakaliki.(2,7) From our data it was observed that the highest numbers of gynaecological malignancies occurred between the ages 50-69 years which is comparable to the findings from Abakaliki and Enugu $(2,3)$. Our study revealed that there is a significant statistical relationship between age of patients and the diagnosis of gynecological malignancies. $(p=0.001)$

Cervical cancer accounted for majority $(60.2 \%)$ of the female genital cancers in this study. This is consistent with results from similar studies in Abakaliki (60.6\%), Ilorin (59.6\%) and Benin $(62.9 \%)(8,9,10)$. It is however slightly higher than the reports from Kano $(48.6 \%)$ but lower than Abuja (65.5\%), Jos (74.9\%) and Zaria $(77.0 \%) .(6,11,12)$. Squamous cell carcinoma constituted $88.4 \%$ of cervical cancer burden in this study, followed by adenocarcinoma (11.6\%), and this is comparable to the findings from other centres in Nigeria.(13)

The mean age at presentation of cervical cancer was $61.5 \pm 14.0$ years. This is higher in comparison to findings documented in Abuja (52.6 years) and Jos (39.5 years). Our study revealed that cervical cancer remains the most common Gynaecological cancer in our environment and this observation is in tandem with those obtained from various studies conducted in west Africa especially in countries like Nigeria and Ghana. $(10,12,14)$.

The probable reason for may be due to some peculiarities like early marriage, high parity, illiteracy, poverty and poor knowledge about cancer screening programs and policies as well as uptake of cervical cancer screening among the women in this region $(14,15)$. Another reason that can be proposed could be because there are very few centres across the country with facilities for cervical cancer screening compared to the teeming population of women who need to access these services $(14,15)$. In some sub-Saharan African countries, this has resulted in the absence of a national cervical cancer screening program and only sporadic screening of women who present to the hospital for gynaecological consultation. It is pertinent to note that where routine cervical cancer screening is practiced, the incidence of invasive cervical cancer is reportedly on the decline $(15,16,17)$. There is therefore the need for increased awareness through outreaches, symposia, educational programs, health talks, etc., to enhance reduction of the menace drastically $(18,19)$.

Ovarian cancer was the second most 
common female genital cancer in this study; accounting for $18.7 \%$ of the cases. This is comparable to reports from Abakaliki ${ }^{2}$ and higher than Jos (15.3\%) but lower than Abuja (22.1\%) and Ilorin $(21.1 \%)(7,9)$. It was however the second most common gynaecological cancers from all these studies. The most common ovarian cancer in this study is the epithelial type, of which serous cystadenocarcinoma is the commonest variety. This is like findings from other centres in Nigeria $(10,11,12)$. The relative lower incidence of ovarian cancer in this study when compared with what obtains in some developed countries, may be due to early marriage and high parity which is common in the developing part of the world, as pregnancy and breast feeding are known to confer protection from ovarian cancers.

Endometrial carcinoma accounted for $13.8 \%$ and the third most common Gynaecological cancer in this study. It occurred more commonly than choriocarcinoma, which accounted for $2.4 \%$. This finding is consistent with the reports from studies done in Abuja and Abakaliki, but different from that reported in Ilorin, Nigeria; where choriocarcinoma was found to be more common than endometrial cancer $(7,8,9,11)$. In our study, choriocarcinoma was found to be more common between the 30-39 age category and were multiparous. This study showed that choriocarcinoma is relatively a disease of younger women and may be so because the disease is associated with pregnancy; hence, it is more likely to occur in active reproductive life (12).

Vaginal and Vulval tumours are generally rare as documented in this study where they constituted $0.8 \%$ and $3.3 \%$ of gynaecological cancers respectively. Vulval cancer findings were similar to that of Ilorin $(3.6 \%)(9)$.

Most women with gynecological cancers in the study were parous, the lowest percentage of women were nulliparous $(5.7 \%)$. There was statistical significance between parity and gynecological cancers with a p-value of 0.001 . The highest incidence of gynaecological cancers was found among Para 5 and above women (56.9\%), however, cervical cancer was common among the multiparous women. This may be due to high parity occurring in Nigeria when compared to other populations where people are aware of the use of family planning methods and actually adopt the use.

It is expedient to note that based on our study it was observed that both ovarian and endometrial cancer were commonly diagnosed among multiparous women. This finding is contrary to previous suggestions that these cancers were more amongst nulliparous women.

Bleeding per vaginam accounted for the commonest presenting complaint amongst patients with cervical and endometrial cancers while ovarian cancers patients commonly presented with abdominal mass or abdominal swelling, ascites, and weight loss. These findings are consistent with similar studies in the past.

Limitations of Study: This was a retrospective study and hence, there were difficulties in obtaining all the required data. It is also hospital based and may not be a true representation of what obtains in the community or the general population. Nevertheless, the health records of patients were all well kept and preserved in the health information and medical records department of the hospital.

\section{CONCLUSION}

According to this study, cancer cervix is the commonest gynaecological malignancy in this population followed by ovarian and endometrial malignancies. Though cancer cervix is a preventable and easily accessible cancer, the incidence is still high in our environment.

Health care policies that allow for strengthening the health programs including regular Pap smear screening, public awareness campaigns, Human Papilloma Virus vaccination and follow up surveillance, prevention, early diagnosis, and treatment of cervical cancer is possible. In low resource settings visual inspection with acetic acid and visual inspection with Lugol's iodine will be quite helpful for early diagnosis and treatment of cervical cancer.(20)

Development of reliable screening methods for endometrial and ovarian cancers is needed to significantly reduce the burden of these cancers. Ancillary measures like the provision of accessible and affordable health care to those who need it most should be strengthened. If all these measures are put in place it will reduce the morbidity and mortality due to gynaecological cancers.

\section{Recommendation}

Gynaecological malignancies constitutes a significant burden in our society hence, there is a need for education and public enlightenment on gynaecological malignancies especially for the commoner malignancies like cervical cancer in which routine screening and treatment of premalignant lesions, better 
organization of cervical screening programmes, effective HPV vaccination and a well-defined follow-up surveillance system will belp to reduce the burden of disease..

Health education and health promotion should be focused on improving awareness on early presentation of patients with gynaecological malignancies

Healthcare insurance policies should be strengthened to allow for increased health seeking behavior amongst individuals with suspected gynaecological malignancies.

There is need for continued research work with the aim of mitigating the suffering of patients with gynaecological malignancies.

Conflict of Interest: There was no conflict of interest during the conduct of this research work

Acknowledgments: We the authors sincerely appreciate the following medical students of Bowen University, Iwo for the various roles they played during the conduct of this research work: Adetoye F, Bowale D, Kasali O, Oladeji I, Oyedele TJ, Salawu BT

\section{REFERENCES}

1. Schiffman M, Castle PE, Jeronimo J, Rodriguez AC, Wacholder S. Human papilloma virus and Cervical Cancer. Lancet. 2007;370:890-907. [PubMed] [Google Scholar]

2. Bouvard V, Baan R, Straif K, et al. A review of human carcinogens--Part B: biological agents. Lancet Oncol. 2009 Apr. 10(4):321-2. [Medline].

3. HIV Infection and Cancer Risk. National Cancer I n s t i t u t e. A v a i l a b l e a t http://www.cancer.gov/cancertopics/factsheet/R isk/hiv-infection. Accessed: February 28, 2012.

4. American College of Obstetricians and Gynecologists. ACOG Practice Bulletin. Clinical management guidelines for obstetrician-gynecologists. Number 61, April 2005. Human papillomavirus. Obstet Gynecol. 2005 Apr. 105 (4):905-18. [Medline].

5. Arends MJ, Wyllie AH, Bird CC. Papillomaviruses and human cancer. Hum Pathol. 1990 Jul. 21(7):686-98. [Medline].

6. Schiffman MH, Bauer HM, Hoover RN. Epidemiologic evidence showing that human papillomavirus infection causes most cervical intraepithelial neoplasia. J Natl Cancer Inst. 1993 Jun 16. 85(12):958-64. [Medline].

7. Osinachi IF, Adewole N, Isah AD, Abdullahi HI and Agida ET (2019). Pattern of gynaecological malignancies in University of Abuja Teaching Hospital Abuja, Nigeria. African Journal of Medical and Health Sciences 19(3):29-35

8. Agboeze J, Ezeonu PO, Onoh RC, Nwali MI,
Agwu MR, Egbuji CC (2015). Frequency and Pattern of Gynecological Cancers in Federal Teaching Hospital, Abakaliki, Nigeria. Journal of Basic and Clinical Reproductive Sciences 4(2):54-57.

9. Ibrahim HM, Ijaiya MA (2013). Pattern of gynaecological malignancies at the University of Ilorin Teaching Hospital, Ilorin, Nigeria. Journal of Obstetrics and Gynaecology 33(2):194-196

10. Okoye CA (2014). Histopathological Pattern of Cervical Cancer in Benin City, Nigeria. The Journal of Medical Investigation Practice 9:147150

11. Yakasai IA, Ugwa EA, Otubu J (2013). Gynecological malignancies in Aminu Kano Teaching Hospital Kano: A 3-year review. Nigerian Journal of Clinical Practice 16(1):6366.

12. Oguntayo O, Zayyan M, Kolawole A, Adewuyi S, Ismail H, Koledade K (2011). Cancer of the cervix in Zaria, Northern Nigeria. Ecancermedicalscience 5(219):1-20.

13. Okeke TC, Onah N, Ikeako LC, Ezenyeaku CCT (2013). The Frequency and Pattern of Female Genital Tract Malignancies at the University of Nigeria Teaching Hospital, Enugu, Nigeria. Annuals of Medical and Health Science Research 3(3):345-348.

14. Iyoke CA, Ugwu GO (2013). Burden of gynaecological cancers in developing countries. World Journal of Obstetrics and Gynaecology 2(1):1-7.

15. The Economist Intelligence Unit (2009). Breakaway: The global burden of cancerchallenges and opportunities. The Economist Intelligence Unit Limited, pp. 1-73.

16. Nwankwo KC, Okafor OC, Ezegwui H (2011). Pattern of Female Genital Tract Malignancy in University of Nigeria Teaching Hospital Enugu. International Journal of Medicine and Health Development 6(1):1-6.

17. Abdullahi H I, Ayogu M E.(2020) Pattern and relative frequencies of gynecological malignancies at the University of Abuja Teaching Hospital, Abuja. Trop J Obstet Gynaecol 37:177-81

18. Omotoso, A. J., Odusolu, P., Ekpe, E. L., Okon, U., \& Oshatuyi, O. (2018). Gynaecological Malignancies in Calabar, Nigeria: A Tertiary Hospital Based Study. Asian Research Journal of Gynaecology and Obstetrics, 1(1), 1-9. $\mathrm{R}$ e $\mathrm{t} \mathrm{r}$ i e $\mathrm{v}$ e d f $\mathrm{r}$ o $\mathrm{m}$ https://journalarjgo.com/index.php/ARJGO/arti cle/view/25497

19. Ajibola Idowu, Samuel Anu Olowookere, Aderonke Tolulope Fagbemi, Olumuyiwa Ayotunde Ogunlaja, "Determinants of Cervical Cancer Screening Uptake among Women in Ilorin, North Central Nigeria: A CommunityBased Study", Journal of Cancer Epidemiology, vol. 2016, Article ID 6469240, 8 pages, 2016.

20. Adeyemi A. Okunowo, Ebunoluwa S. Daramola, 
Adaiah P. Soibi-Harry, Francis C. Ezenwankwo, Jubril O. Kuku, Kehinde S. Okunade, Rose I. Anorlu, Women's knowledge of cervical cancer and uptake of Pap smear testing and the factors influencing it in a Nigerian tertiary hospital,Journal of Cancer Research and Practice, Volume 5, Issue 3,2018,Pages 105-111

How to cite this article: 
Table 1- shows the relationship between various forms of gynaecological malignancies and age

\begin{tabular}{|c|c|c|c|c|c|c|c|}
\hline Cervical & Ovarian & Endometrial & Choriocarcinoma & Vulva & Vaginal & Uterine & $\overline{\text { Sum }}$ \\
\hline 1 & 0 & 0 & 0 & 0 & 0 & 0 & 1 \\
\hline 1 & 1 & 0 & 3 & 0 & 0 & 0 & 5 \\
\hline 14 & 7 & 1 & 0 & 0 & 0 & 0 & 22 \\
\hline 16 & 9 & 9 & 0 & 0 & 1 & 0 & 35 \\
\hline 20 & 6 & 5 & 0 & 3 & 0 & 1 & 35 \\
\hline 13 & 0 & 2 & 0 & 1 & 0 & 0 & 16 \\
\hline 6 & 0 & 0 & 0 & 0 & 0 & 0 & 6 \\
\hline 3 & 0 & 0 & 0 & 0 & 0 & 0 & 3 \\
\hline 74 & 23 & 17 & 3 & 4 & 1 & 1 & 123 \\
\hline $61.5 \pm 14$ & $51.8 \pm 8.48$ & $57.9 \pm 6.81$ & $37.3 \pm 1.15$ & $66.25 \pm 2.5$ & $57 \pm 0$ & $60 \pm 0$ & \\
\hline
\end{tabular}

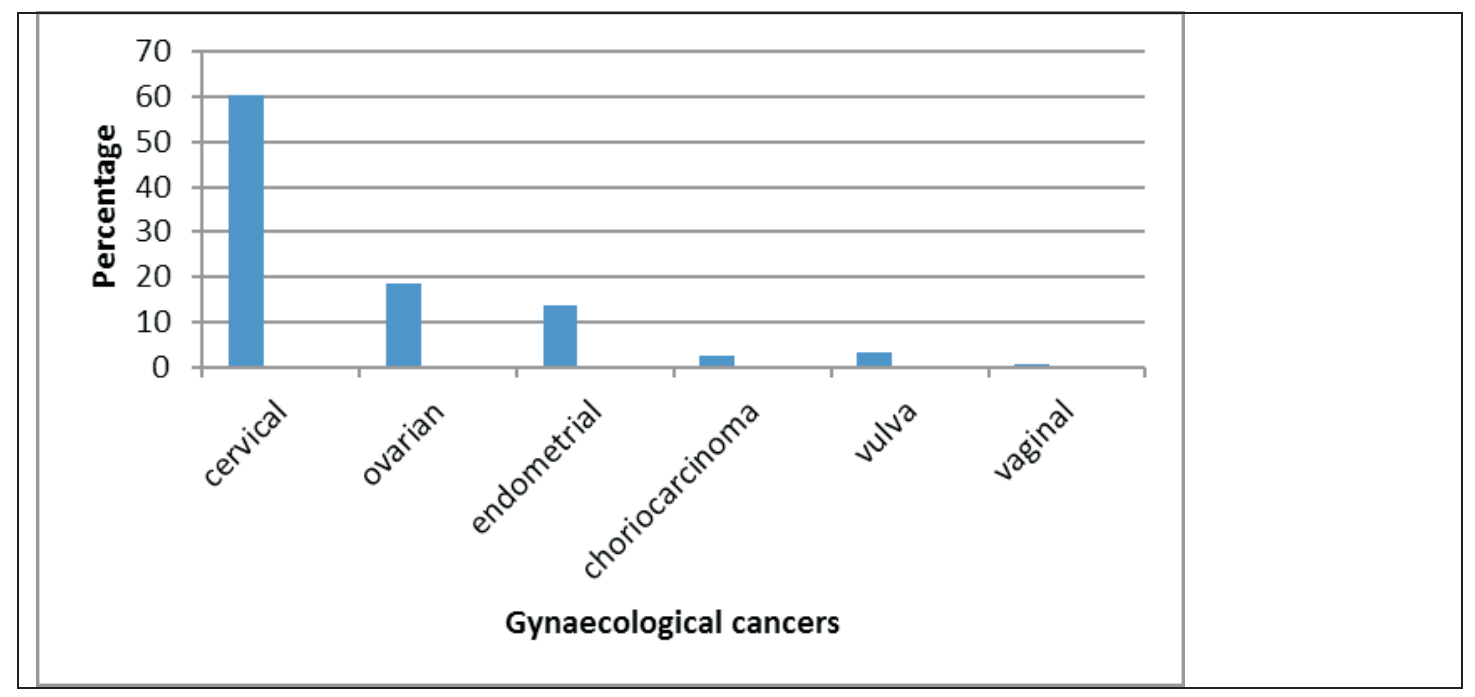

Figure 1. The prevalence of gynaecological cancers as seen in BUTH, Ogbomoso

Table 2 - Pattern of presentation of gynaecological malignancies at BUTH, Ogbomoso

\begin{tabular}{|c|c|c|c|c|c|c|c|}
\hline $\begin{array}{l}\text { Presenting } \\
\text { complaint }\end{array}$ & Cervical & Ovarian & Endometria & Choriocarcinoma & Vulva & Vaginal & Uterine \\
\hline $\begin{array}{l}\text { Bleeding } \\
\text { Per Vagina }\end{array}$ & 61 & 2 & 13 & 1 & 2 & 0 & 0 \\
\hline $\begin{array}{l}\text { Vaginal } \\
\text { Discharge }\end{array}$ & 24 & 1 & 6 & 0 & 3 & 0 & 1 \\
\hline $\begin{array}{l}\text { Abdominal } \\
\text { Mass }\end{array}$ & 4 & 16 & 4 & 2 & 0 & 0 & 1 \\
\hline Pelvic Mass & 4 & 1 & 3 & 0 & 0 & 0 & 1 \\
\hline $\begin{array}{l}\text { Abdominal } \\
\text { Pain }\end{array}$ & 21 & 3 & 7 & 2 & 2 & 0 & 1 \\
\hline Ascites & 1 & 11 & 1 & 0 & 0 & 0 & 0 \\
\hline $\begin{array}{l}\text { Weight } \\
\text { Loss }\end{array}$ & 35 & 12 & 2 & 2 & 2 & 0 & 0 \\
\hline $\begin{array}{l}\text { Vaginal } \\
\text { Mass }\end{array}$ & 0 & 0 & 0 & 0 & 0 & 1 & 0 \\
\hline
\end{tabular}

